\title{
NMDA Receptor Regulation Is Involved in the Limitation of Physiological Tolerance to Both Low Temperature and High Hydrostatic Pressure
}

\author{
Alastair Brown* and Sven Thatje \\ Ocean and Earth Science, National Oceanography Centre Southampton, University of Southampton, Southampton, \\ United Kingdom
}

Keywords: NMDA receptor, neurotransmission, low temperature, high hydrostatic pressure, crustacea

OPEN ACCESS

Edited by:

Youji Wang,

Shanghai Ocean University, China

Reviewed by:

Gustavo Núñez-Acuña,

University of Concepción, Chile

Michael A. Menze,

University of Louisville, United States

Yoram Grossman,

Ben-Gurion University of the Negev,

Israel

*Correspondence:

Alastair Brown

alastair.brown@noc.soton.ac.uk

Specialty section:

This article was submitted to

Aquatic Physiology,

a section of the journal

Frontiers in Marine Science

Received: 20 November 2017 Accepted: 06 March 2018 Published: 20 March 2018

Citation: Brown A and Thatje S (2018) NMDA Receptor Regulation Is Involved in the Limitation of Physiological Tolerance to Both Low Temperature and High

Hydrostatic Pressure.

Front. Mar. Sci. 5:93.

doi: 10.3389/fmars.2018.00093
Polar and deep marine environments are physiologically challenging to invertebrates. Low temperature and high hydrostatic pressure both reduce the functionality of membranes, affect the function of macromolecules, and induce macromolecular damage, with diverse physiological consequences that have resulted in physiological adaptation among taxa inhabiting these environments (see Pörtner and Playle, 2010; Sébert, 2010 and references cited therein). The similar molecular and cellular effects of, and adaptations to, low temperature and high hydrostatic pressure have prompted the hypothesis that a common mechanism underlies physiological tolerance to both factors (Brown and Thatje, 2014, 2015). The physiological concept of oxygen- and capacity-limited thermal tolerance describes a mechanism where temperature tolerance is constrained by the ability to supply sufficient oxygen to meet metabolic demand (Pörtner, 2010). Recent experimental evidence indicates that hyperbaric tolerance is oxygen- and capacity-limited, too (Brown et al., 2017). However, whether the same fundamental mechanism limits both temperature and hydrostatic pressure tolerance, and what that mechanism may be, remains uncertain. Here, we synthesize relevant literature focusing on reptant decapods, the invertebrate taxon with most thoroughly explored low temperature $\left(<5^{\circ} \mathrm{C}\right)$ and high hydrostatic pressure $(>5 \mathrm{MPa} \approx>500 \mathrm{~m}$ depth) tolerance, and identify a potential mechanism limiting tolerance of both environmental factors.

Thermal cardiac dependence in crustaceans is predominantly mediated by temperature effects on the cardiac ganglion (Worden et al., 2006). Temperature-dependent mechanisms of synaptic transmission and pre- and post-synaptic transmitter-receptor interactions are putatively critical to temperature-dependent cardiac function in crustaceans (Frederich et al., 2000a,b). Neurotransmitter release is reduced at low temperature (Dunn and Mercier, 2003), which contributes to reducing neuromuscular transmission and consequently heart rate (Wittmann et al., 2010). However, inability to down-regulate haemolymph $\left[\mathrm{Mg}^{2+}\right]$ has been implicated in constraining low-temperature tolerance and range limitation in reptant decapods (Frederich et al., 2000a,b): neurostransmitter release is also reduced at high extracellular $\left[\mathrm{Mg}^{2+}\right]$ (Parnas et al., 1994). Reduction of ambient $\left[\mathrm{Mg}^{2+}\right]$ typically increases heart rate and metabolic rate performance at low temperature in reptant decapods (Frederich et al., 2000a,b) due to reduced neurotransmission interference (Wittmann et al., 2010). The negative correlation between heart rate and haemolymph $\left[\mathrm{Mg}^{2+}\right]$ in decapods may, therefore, depend on calcium channel blockade by magnesium, which slows neuromuscular transmission (see Wittmann et al., 2010, and references cited therein).

Moderating $\left[\mathrm{Mg}^{2+}\right]$-dependent thermal tolerance appears to have been critical to the relative success of lithodid crabs at extremely low, polar temperatures $\left(\leq 2^{\circ} \mathrm{C}\right)$ (Wittmann et al., 2012). 
Lithodid crabs dominate reptant decapod occurrences approaching Antarctica (see Griffiths et al., 2013, and references cited therein) - the lowest temperature marine environment. However, recent experimental evidence suggests that the temperature-dependent mechanism of synaptic transmission, and pre- and postsynaptic transmitter-receptor interaction may be more critical to temperature-dependent physiological function in lithodids than $\left[\mathrm{Mg}^{2+}\right]$ regulation (Wittmann et al., 2011, 2012). Nonetheless, experimental evidence indicates that heartbeat and ventilation beat frequencies in lithodids remain affected by $\left[\mathrm{Mg}^{2+}\right]$ (Wittmann et al., 2012). The lithodid crab Lithodes maja appears capable of greater haemolymph $\left[\mathrm{Mg}^{2+}\right]$ down-regulation than other examined lithodids (cf. Wittmann et al., 2010; Brown, 2015) and is reported in colder waters $\left(0^{\circ} \mathrm{C}\right)$ than Southern Ocean lithodids $\left(0.2^{\circ} \mathrm{C}\right)$ (cf. Hall and Thatje, 2011; Brown et al., 2017). Consistent with this hypothesis, heart rate is greater in L. maja than in the sub-Antarctic lithodid Paralomis granulosa at $0.1 \mathrm{MPa}$ and $6^{\circ} \mathrm{C}$; respectively $\sim 28 \mathrm{bpm}$ and $\sim 21$ bpm at rest (Wittmann et al., 2012). Co-occurring differences in thermal distribution and in $\left[\mathrm{Mg}^{2+}\right]$ regulation suggest that $\left[\mathrm{Mg}^{2+}\right]$ regulation remains capacity limiting in lithodids.

Hyperbaric tolerance in L. maja is also limited by hyperbaric effects on heart rate (Brown et al., 2017). Decreasing heart rate observed in L. maja in response to increasing hydrostatic pressure is similar to the decrease in heart rate observed in $P$. granulosa in response to decreasing temperature, suggesting that $\left[\mathrm{Mg}^{2+}\right]$ regulation may also critically influence hyperbaric performance. Linear regression indicates that heart rate decreases by $1.01 \mathrm{bpm}{ }^{\circ} \mathrm{C}^{-1}$ in P. granulosa (Wittmann et al., 2012) and by $0.889 \mathrm{bpm} \mathrm{MPa}^{-1}$ in L. maja (Brown et al., 2017). Disparity between hydrostatic pressure thresholds in relatively effective and ineffective haemolymph $\left[\mathrm{Mg}^{2+}\right]$-regulating crustaceans supports this interpretation. Hydrostatic pressure tolerances are significantly lower in decapod taxa typically incapable of regulating haemolymph $\left[\mathrm{Mg}^{2+}\right]$ concentration below $90 \%$ ambient seawater (anomurans and brachyurans) than in decapod taxa typically capable of doing so (amphipods, carideans, and isopods) [one-way ANOVA: $F_{(1,13)}=9.292, p=0.009$; for data see Brown and Thatje, 2015]. $\left[\mathrm{Mg}^{2+}\right]$ regulation may therefore be involved in limiting both low temperature and high hydrostatic pressure tolerance, but through what mechanism/s? $\mathrm{Mg}^{2+}$ may directly influence cardiac muscle activity at low temperature high hydrostatic pressure by inhibiting activity in myosin motors (Hogan and Besch, 1993). However, cardiac activity in decapod crustaceans is neurogenic (Anderson and Cooke, 1971) and low temperature high hydrostatic pressure effects on neurotransmission may precede effects on muscle activity (Friedrich, 2010). We therefore hypothesize that $\left[\mathrm{Mg}^{2+}\right]$ regulation contributes to limiting tolerance to both low temperature and high hydrostatic pressure through effects on $N$-methyl-D-aspartate (NMDA) receptors.

NMDA receptors are ligand-gated and voltage dependent glutamate receptors: ion channels that mediate excitatory neurotransmission (Dingledine et al., 1999). NMDA receptors appear to be concentrated in all major ganglia of decapods, demonstrating strong localization in synaptosomal membranes (Hepp et al., 2013). Inhibition of NMDA receptor activity depends predominantly on $\mathrm{Mg}^{2+}$ blockade (Blanke and Van Dongen, 2009), although $\mathrm{Zn}^{2+}$ can also inhibit NMDA receptor function (Amico-Ruvio et al., 2011). Information on $\left[\mathrm{Zn}^{2+}\right]$ regulation in decapod crustaceans is extremely limited (Lignot and Charmantier, 2015), precluding thorough exploration of the potential contribution of $\left[\mathrm{Zn}^{2+}\right]$ regulation to limitation of low temperature tolerance. However, improvements in reptant decapod low-temperature performance with decreased ambient $\left[\mathrm{Mg}^{2+}\right]$ (including heart rate and metabolic rate; Frederich et al., 2000a,b, 2001) suggest that low-temperature neurotransmission interference may result from NMDA receptor under-activity. Indeed, shifts in NMDA receptor regulation occur during cold stress in reptant decapods (Stillman and Tagmount, 2009).

The hyperbaric decrease in L. maja's heart rate may also be mediated by depressed neurotransmission, resulting from shifts in NMDA receptor activity (Brown et al., 2017). Indeed, pressure depresses synaptic transmission at all examined synapses in shallow-water taxa (see Aviner et al., 2010), including the crustacean neuromuscular junction (Campenot, 1975). Studies in vertebrates indicate that pressure can diminish the efficacy of receptor blockade and augment NMDA receptor synaptic responses, leading to hyper-excitability, and potentially to neurotoxicity through excessive cellular influx of $\mathrm{Ca}^{2+}$ (Mor and Grossman, 2006, 2007, 2010). NMDA receptor stimulation certainly appears to significantly increase hyperbaric sensitivity (Millan et al., 1989; Darbin et al., 2000). However, neural and muscular symptoms of hydrostatic pressure effects are also compatible with slowing NMDA receptor kinetics (e.g., Talpalar and Grossman, 2006). Shifts in NMDA receptor activity may result from impaired rather than augmented NMDA receptor function. NMDA receptor subtypes display differential responses to elevated pressure, and ionic currents can be decreased rather than increased by elevated pressure (Mor et al., 2012).

Mor et al. (2012) examined eight NMDA receptor subtypes for responses to high pressure $(10.1 \mathrm{MPa})$ and reported that only one subtype produced significantly larger ionic current at high pressure, whereas ionic currents in three subtypes appeared unresponsive to high pressure, and four subtypes produced significantly smaller ionic currents at high pressure. Acute cold reduces voltage-dependent $\mathrm{Ca}^{2+}$ channel currents similarly and prolongs action potential duration, reducing $\mathrm{Ca}^{2+}$ flux and depressing cardiac contractility (e.g., Shiels et al., 2014). Hydrostatic pressure effects on membrane properties and ion channel structure (Tillman and Cascio, 2003) may affect quaternary structure, destabilizing the ligandbinding cores of glutamate receptors enhancing neurotransmitter desensitization (Sun et al., 2002). However, further exploration has revealed that high pressure effects on NMDA receptor subtypes can vary among different splice variants (Bliznyuk et al., 2015), even switching between increasing and decreasing ionic currents (Bliznyuk et al., 2017). The mechanism underlying the switch remains unknown (Bliznyuk et al., 2017). Whether decapod crustaceans have a similar diversity of receptor subtypes is unknown, but the arthropod Drosophila spp. demonstrates the alternative splicing that generates different gene transcripts encoding different protein isoforms, which may form different receptor subtypes (Xia et al., 2005), 
suggesting that crustaceans may also possess different receptor subtypes. Nonetheless, the function of decapod NMDA receptor subtypes may still differ from function identified in other taxa.

Variation in $\left[\mathrm{Mg}^{2+}\right]$ regulation among decapod crustaceans highlights the potential influence of glutamergic NMDA synaptic processes in limitation of high hydrostatic pressure tolerance. NMDA receptors typically have higher $\mathrm{Ca}^{2+}$ conductance than other synaptic receptors (Aviner et al., 2010) suggesting greater potential for high hydrostatic pressure impact on neurotransmission than other synaptic receptors. However, high hydrostatic pressure affects glutamergic AMPA, GABAergic, glycinergic, dopaminic, serotonergic, and cholinergenic synaptic processes similarly (Grossman et al., 2010), likely contributing to limitation of high hydrostatic pressure tolerance. The effects of high hydrostatic pressure on other ion channels may contribute to limitation of high hydrostatic pressure, too. For example, high hydrostatic pressure impairs the function of $\mathrm{Na}^{+}, \mathrm{K}^{+}$-ATPase (Gibbs and Somero, 1989). $\mathrm{Na}^{+}, \mathrm{K}^{+}$-ATPase contributes to $\mathrm{Ca}^{2+}$ homeostasis in crustaceans (Freire et al., 2008) and is critical to maintaining membrane potential needed to generate action potentials in cells regulating cardiac function (Lodish et al., 2003). Indeed, $\mathrm{Na}^{+}, \mathrm{K}^{+}$-ATPase dysfunction can eventually render the crustacean heart unable to beat (Stillman, 2002). Critical pressure effects on $\mathrm{Na}^{+}, \mathrm{K}^{+}$-ATPase are supported by enzymatic functional pressure-adaptation in deep-sea organisms (Gibbs and Somero, 1989). However, the $\mathrm{Na}^{+}, \mathrm{K}^{+}$-ATPase function is reduced by high hydrostatic pressure in a nonlinear decrease (Gibbs and Somero, 1989), in contrast to the linear decrease in hyperbaric heart rate (Brown et al., 2017). Regardless, the apparent influence of $\left[\mathrm{Mg}^{2+}\right]$ on high hydrostatic pressure tolerance suggests a significant

\section{REFERENCES}

Amico-Ruvio, S. A., Murthy, S. E., Smith, T. P., and Popescu, G. K. (2011). Zinc effects on NMDA receptor gating kinetics. Biophys. J. 100, 1910-1918. doi: 10.1016/j.bpj.2011.02.042

Anderson, M., and Cooke, I. M. (1971). Neural activation of the heart of the lobster Homarus americanus. J. Exp. Biol. 55, 449-468.

Aviner, B., Gnatek, Y., Gradwohl, G., and Grossman, Y. (2010). Hyperbaric pressure effects on voltage-dependent $\mathrm{Ca}^{2+}$ channels: relevance to HPNS. Undersea Hyperbar. M. 37, 245-258.

Blanke, M. L., and Van Dongen, A. M. J. (2009). "Activation mechanisms of the NMDA receptor," in Biology of the NMDA Receptor, ed A. M. J. Van Dongen (New York, NY:CRC Press), 283-312.

Bliznyuk, A., Aviner, B., Golan, H., Hollmann, M., and Grossman, Y. (2015). The N-methyl-D-aspartate receptor's neglected subunit - GluN1 matters under normal and hyperbaric conditions. Euro. J. Neurosci. 42, 2577-2584. doi: $10.1111 /$ ejn.13022

Bliznyuk, A., Gradwohl, G., Hollmann, M., and Grossman, Y. (2017). The enigma of the dichotomic pressure response of GluN1-4a/b splice variants of NMDA receptor: experimental and statistical analyses. Front. Mol. Neurosci. 9:40. doi: $10.3389 /$ fnmol.2016.00040

Brown, A. (2015). The Role of Pressure in Constraining the Bathymetric Distribution of Marine Ectotherms. Ph.D thesis. University of Southampton.

Brown, A., and Thatje, S. (2014). Explaining bathymetric diversity patterns in marine benthic invertebrates and demersal fishes: physiological contributions to adaptation of life at depth. Biol. Rev. 89, 406-426. doi: 10.1111/brv.12061 role for NMDA receptors in limitation of high hydrostatic pressure.

Testing the role of NMDA receptors in limiting tolerance of high hydrostatic pressure may be achieved by assessing the hyperbaric performance of reptant decapods in seawater with reduced $\left[\mathrm{Mg}^{2+}\right]$. However, resolving the relative importance of NMDA receptor subtypes and splice variants and other ion channels to low temperature and high hydrostatic pressure tolerance in decapod Crustacea will require exploration of latitudinal and bathymetric trends in adaptation in these structures. Such study may be crucial to understanding potential future impacts of changing climate on deep-sea ecosystems: the interaction of low temperature and high hydrostatic pressure establishes a physiological bottleneck at bathyal depths (Brown and Thatje, 2014), which will be affected by ocean warming (Brown and Thatje, 2015).

\section{AUTHOR CONTRIBUTIONS}

$\mathrm{AB}$ conceived and performed the synthesis. $\mathrm{AB}$ wrote the manuscript and ST contributed critically to the drafts.

\section{FUNDING}

$\mathrm{AB}$ was supported through a Natural Environment Research Council (NERC) PhD studentship and a Collaborative Award in Science and Engineering from Transocean.

\section{ACKNOWLEDGMENTS}

This paper includes content from AB's PhD thesis (Brown, 2015).

Brown, A., and Thatje, S. (2015). The effects of changing climate on faunal depth distributions determine winners and losers. Glob. Change Biol. 21, 173-180. doi: $10.1111 /$ gcb. 12680

Brown, A., Thatje, S., Morris, J. P., Oliphant, A., Morgan, E. A., Hauton, C., et al. (2017). Metabolic costs imposed by hydrostatic pressure constrain bathymetric range in lithodid crab Lithodes maja. J. Exp. Biol. 220(Pt 21), 3916-3926. doi: $10.1242 /$ jeb.158543

Campenot, R. B. (1975). The effects of high hydrostatic pressure on transmission at the crustacean neuromuscular junction. Comp. Biochem. Physiol. 52B, 133-140. doi: 10.1016/0305-0491(75)90128-5

Darbin, O., Risso, J. J., and Rostain, J. C. (2000). High pressure enhanced NMDA activity in the striatum and the globus pallidus: relationships with myoclonia and locomotor and motor activity in rat. Brain Res. 852, 62-67. doi: 10.1016/S0006-8993(99)02195-2

Dingledine, R., Borges, K., Bowie, D., and Traynelis, S. F. (1999). The glutamate receptor ion channels. Pharma. Rev. 51, 7-61.

Dunn, T. W., and Mercier, A. J. (2003). Synaptic modulation by a neuropeptide depends on temperature and extracellular calcium. J. Neurophysiol. 89, 1807-1814. doi: 10.1152/jn.00710.2002

Frederich, M., DeWachter, B., Sartoris, F. J., and Pörtner, H. O. (2000a). Cold tolerance and the regulation of cardiac performance and hemolymph distribution in Maja squinado (Crustacea: Decapoda). Physiol. Biochem. Zool. 73, 406-415. doi: 10.1086/317735

Frederich, M., Sartoris, F. J., Arntz, W. E., and Pörtner, H. O. (2000b). Haemolymph $\mathrm{Mg}^{2+}$ regulation in decapod crustaceans: physiological correlates and ecological consequences in polar areas. J. Exp. Biol. 203, 1383-1393. 
Frederich, M., Sartoris, F. J., and Pörtner, H.-O. (2001). Distribution patterns of decapod crustaceans in polar waters: a result of magnesium regulation? Polar Biol. 24, 719-723. doi: 10.1007/s003000100270

Freire, C. A., Onken, H., and McNamara, J. C. (2008). A structure-function analysis of ion transport in crustacean gills and excretory organs. Comp. Biochem. Physiol. A 151, 272-304. doi: 10.1016/j.cbpa.2007.05.008

Friedrich, O. (2010). "Muscle function and high hydrostatic pressures," in Comparative High Pressure Biology, ed P. Sébert (Enfield: Science Publishers), 210-249.

Gibbs, A., and Somero, G. N. (1989). Pressure adaptation of $\mathrm{Na}^{+} / \mathrm{K}^{+}$ATPase in gills of marine teleosts. J. Exp. Biol. 143, 475-492.

Griffiths, H. J., Whittle, R. J., Roberts, S. J., Belchier, M., and Linse, K. (2013). Antarctic crabs: invasion or endurance? PLoS ONE 8:e66981. doi: 10.1371/journal.pone.0066981

Grossman, Y., Aviner, B., and Mor, A. (2010). "Pressure effects on mammalian central nervous system," in Comparative High Pressure Biology, ed P. Sébert (Enfield: Science Publishers), 161-186.

Hall, S., and Thatje, S. (2011). Temperature-driven biogeography of the deep-sea family Lithodidae (Crustacea: Decapoda: Anomura) in the Southern Ocean. Polar Biol. 34, 363-370. doi: 10.1007/s00300-010-0890-0

Hepp, Y., Tano, M. C., Pedreira, M. E., and Freudenthal, R. A. (2013). NMDA-like receptors in the nervous system of the crab Neohelice granulata: a neuroanatomical description. J. Comp. Neurol. 521, 2279-2297. doi: $10.1002 / \mathrm{cne} .23285$

Hogan, P. M., and Besch, S. R. (1993). "Vertebrate skeletal and cardiac muscle," in Effects of High Pressure on Biological Systems, ed A. G. Macdonald (Berlin: Springer-Verlag), 125-146.

Lignot, J.-H., and Charmantier, G. (2015). "Osmoregulation and excretion," in Physiology, The Natural History of the Crustacea Volume 4, eds E. Chang and M. Thiel (Oxford: Oxford University Press), 249-284.

Lodish, H., Berk, A., Matsudaira, P., Kaiser, C. A., Krieger, M., Scott, M. P., et al. (2003). Molecular Cell Biology (5th edition). New York, NY: WH Freeman and Company.

Millan, M. H., Wardley-Smith, B., Halsey, M. J., and Meldrum, B. S. (1989). Studies on the role of the NMDA receptor in the substantia nigra pars reticulata and entopeduncular nucleus in the development of the high pressure neurological syndrome in rats. Exp. Brain Res. 78, 174-178. doi: 10.1007/BF00230696

Mor, A., and Grossman, Y. (2006). Modulation of isolated N-methyl-Daspartate receptor response under hyperbaric conditions. Euro. J. Neurosci. 24, 3453-3462. doi: 10.1111/j.1460-9568.2006.05233.x

Mor, A., and Grossman, Y. (2007). High pressure modulation of NMDA receptor dependent excitability. Euro. J. Neurosci. 25, 2045-2052. doi: 10.1111/j.1460-9568.2007.05479.x

Mor, A., and Grossman, Y. (2010). The efficacy of physiological and pharmacological N-methyl-D-aspartate receptor block is greatly reduced under hyperbaric conditions. Neuroscience 169, 1-7. doi: 10.1016/j.neuroscience.2010.05.009

Mor, A., Kuttner, Y. Y., Levy, S., Mor, M., Hollmann, M., and Grossman, Y. (2012). Pressure-selective modulation of NMDA receptor subtypes may reflect 3D structural differences. Front. Cell. Neurosci. 6:37. doi: 10.3389/fncel.2012.00037

Parnas, H., Parnas, I., Ravin, R., and Yudelevitch, B. (1994). Glutamate and N-methyl-D-aspartate affect release from crayfish axon terminals in a voltage-dependent manner. Proc. Natl. Acad. Sci. U.S.A. 91, 11586-11590. doi: $10.1073 /$ pnas.91.24.11586
Pörtner, H. O. (2010). Oxygen- and capacity-limitation of thermal tolerance: A matrix for integrating climate-related stressor effects in marine ecosystems. $J$. Exp. Biol. 213, 881-893. doi: 10.1242/jeb.037523

Pörtner, H. O., and Playle, R. C. (2010). Cold Ocean Physiology. Cambridge: Cambridge University Press.

Sébert, P. (2010). Comparative High Pressure Biology. Enfield: Science Publishers.

Shiels, H. A., Galli, G. L., and Block, B. A. (2014). Cardiac function in an endothermic fish: cellular mechanisms for overcoming acute thermal challenges during diving. Proc. R. Soc. B 282:20141989. doi: $10.1098 / \mathrm{rspb} .2014 .1989$

Stillman, J. H. (2002). Causes and consequences of thermal tolerance limits in rocky intertidal porcelain crabs, genus Petrolisthes. Integr. Comp. Biol. 42, 790-796. doi: 10.1093/icb/42.4.790

Stillman, J. H., and Tagmount, A. (2009). Seasonal and latitudinal acclimatization of cardiac transcriptome responses to thermal stress in porcelain crabs, Petrolisthes cinctipes. Mol. Ecol. 18, 4206-4226. doi: 10.1111/j.1365-294X.2009.04354.x

Sun, Y., Olson, R., Horning, M., Armstrong, N., Mayer, M., and Gouaux, E. (2002). Mechanism of glutamate receptor desensitization. Nature 417, 245-253. doi: $10.1038 / 417245$ a

Talpalar, A. E., and Grossman, Y. (2006). CNS manifestations of HPNS: revisited. Undersea Hyperbar. M. 33, 205-210.

Tillman, T. S., and Cascio, M. (2003). Effects of membrane lipids on ion channel structure and function. Cell Biochem. Biophys. 38, 161-190. doi: 10.1385/CBB:38:2:161

Wittmann, A. C., Held, C., Pörtner, H. O., and Sartoris, F. J. (2010). Ion regulatory capacity and the biogeography of Crustacea at high southern latitudes. Polar Biol. 33, 919-928. doi: 10.1007/s00300-010-0768-1

Wittmann, A. C., Pörtner, H. O., and Sartoris, F. J. (2012). A role for oxygen delivery and extracellular magnesium in limiting cold tolerance of the subAntarctic stone crab Paralomis granulosa? Physiol. Biochem. Zool. 85, 285-298. doi: $10.1086 / 665328$

Wittmann, A. C., Storch, D., Anger, K., Pörtner, H. O., and Sartoris, F. J. (2011). Temperature-dependent activity in early life stages of the stone crab Paralomis granulosa (Decapoda, Anomura, Lithodidae): a role for ionic and magnesium regulation? J. Exp. Mar. Biol. Ecol. 397, 27-37. doi: 10.1016/j.jembe.2010. 11.005

Worden, M. K., Clark, C. M., Conaway, M., and Qadri, S. A. (2006). Temperature dependence of cardiac performance in the lobster Homarus americanus. J. Exp. Biol. 209, 1024-1034. doi: 10.1242/jeb.02082

Xia, S., Miyashita, T., Fu, T. F., Lin, W. Y., Wu, C. L., Pyzocha, L., et al. (2005). NMDA receptors mediate olfactory learning and memory in Drosophila. Curr. Biol. 15, 603-615. doi: 10.1016/j.cub.2005.02.059

Conflict of Interest Statement: The authors declare that the research was conducted in the absence of any commercial or financial relationships that could be construed as a potential conflict of interest.

Copyright (c) 2018 Brown and Thatje. This is an open-access article distributed under the terms of the Creative Commons Attribution License (CC BY). The use, distribution or reproduction in other forums is permitted, provided the original author(s) and the copyright owner are credited and that the original publication in this journal is cited, in accordance with accepted academic practice. No use, distribution or reproduction is permitted which does not comply with these terms. 